\title{
Relative production efficiency of maize-legume intercroppings at different altitudes
}

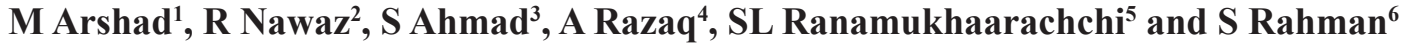 \\ ${ }^{I}$ Department of Agriculture \& Food Technology, Karakoram International University, Gilgit, Pakistan. \\ ${ }^{2}$ Department of Environmental Sciences, Faculty of Sciences, The University of Lahore, Pakistan. \\ ${ }^{3}$ Department of Environmental Sciences, COMSATS University Islamabad, Vehari Campus, Pakistan. \\ ${ }^{4}$ Department of Biological Sciences, Karakoram International University, Gilgit, Pakistan. \\ ${ }^{5}$ Agricultural Technology Program, Sri Lanka Technological Campus, Meepe, Padukka. \\ ${ }^{6}$ Department of Mathematics, Karakoram International University, Gilgit, Pakistan.
}

Submitted: 29 July 2019; Revised: 20 April 2020; Accepted: 18 August 2020

\begin{abstract}
Incessant monocropping of more nutrient consuming maize leads to subsequent land deterioration, gradual food productivity reductions, and challenges the sustainability of local food production systems. Research trials were conducted for three years $(2015,2016$ and 2017) to assess the equivalent yield (EY) of maize and relative production efficiency (RPE) of intercropping of maize with four legumes at three different altitudes (1500, 1800 and 2200 MASL) using randomised complete block design (RCBD) with three blocks. In 2015, maize was intercropped with mungbean and fababean using three nitrogen $(\mathrm{N})$ levels $\left(28,56,113 \mathrm{~kg} \mathrm{~N} \mathrm{ha}^{-1}\right)$ and in 2016, with mungbean and cowpea using two types of row arrangements (alternate single row, alternate double row). In 2017, maize was intercropped with mungbean and soybean with two types of seeding times, namely, simultaneous and staggered. Monocropping of maize and each of the legumes were also arranged for comparison at each location. Statistical results indicated the differences of EY and RPE among the altitudes, $\mathrm{N}$ doses, row patterns and time of sowing. Values of EY and RPE were greater at $1500 \mathrm{~m}$ altitude and for intercropping (maize + legume) established with a $\mathrm{N}$ dose of $113 \mathrm{~kg} \mathrm{~N}^{-1}$ with alternate single row arrangement and staggered sowing. On the basis of RPE, intercropping of maize with mungbean is recommended for cultivation.
\end{abstract}

Keywords: Altitude, mungbean, nitrogen, row pattern, relative yield, simultaneous sowing, staggered sowing.

\section{INTRODUCTION}

Intensive and extensive cultivation of monocultures is an inherent threat to agro-biodiversity, soil resources and sustainability of agroecosystems. A monocropping system limits the opportunities to a variety of biological populations through restricting their access to diverse food resources for survival in an agroecosystem. Maize is cultivated in wider inter-row spacing to reduce intraspecific adverse interaction and for greater solar radiation interception by lower leaves at its peak vegetative growth stages. It has slow growth at initial growth stages while leaving the inter-row spacing uncovered, exposing to evaporative losses of soil water content, soil erosion by irrigation water flows and also serves as a potential resource for the germination of weeds. The establishment of legume cover at inter-row spacing of maize during early growth stages helps protect soil moisture loss, reduced weed germination and soil erosion vulnerability especially on sloping surfaces in mountainous areas. When two or more crop species are cultivated in the vicinity, interspecific competition for light available above and resources under soil surface (nutrients, water) is certain. Such competition especially during limited availability of the resources leads to lower

"Corresponding author (dr.arshad@kiu.edu.pk; (iD https://orcid.org/0000-0001-6016-5040)

This article is published under the Creative Commons CC-BY-ND License (http://creativecommons.org/licenses/by-nd/4.0/). This license permits use, distribution and reproduction, commercial and non-commercial, provided that the original work is properly cited and is not changed in anyway. 
average production of intercrops. In contrast, greater variability and lower commonality of the requirements of intercrops lead to reduced competition. Hence, interspecific competition between maize and legume intercropping may be reduced to a greater extent through temporal separation of peak growth periods and spatial difference of root zone profiles.

Intercropping cereals with legumes is an opportunity for lowland and resource-deficit farmers to cultivate more than one crop on the same land and during a season to harness yield and economic benefits (Seran \& Brintha, 2010). Multiple advantages associated with intercropping cereals with legumes have been highlighted by different scientists (Sharma et al., 2000; Zougmore et al., 2000; Ayub et al., 2004; Arshad \& Ranamukhaarachchi, 2012; Wang et al., 2014; Zhang et al., 2015). Compared to conventional monocropping, intercropping tall species with short stature crops, in appropriate row arrangement and time of sowing increase light and water use efficiency leading to higher grain production (Amjadian et al., 2013; Dhar et al., 2013).

Competition between component crops in intercropping is likely and it is quite important to know its nature to devise an appropriate strategy to decrease the competition to a possible extent. Time-based separation can be practiced as a relay or staggered sowing, where the second crop is sown near the beginning of reproductive stage of the former crop that can be harvested to make room for full growth and development of the later crop (Lithourgidis et al., 2011). In staggered sowing, a slight overlap of growth periods of the crops is expected and severity of competitiveness of the crops is reduced to a greater extent (Arshad \& Ranamukhaarachchi, 2012). This staggering of sowing time of maize and legumes overcomes the competition through creation of a competition-free duration during early and fast growing stages. Therefore, staggering makes it possible to have legume in the cropping system where the adjacent cereal receives benefits of $\mathrm{N}$ fixed by the well grown legume in the vicinity. Addo-Quaye et al. (2011) executed two field trials to examine the suitable sequence of planting maize with soybean in intercropping, and concluded that maize sown simultaneously or prior to soybean yielded significantly higher leaf area index (LAI), crop growth rate (CGR) and net assimilation rate (NAR) compared to monocropping of maize. In this connection, Marinus (2014) stated that addition of short-duration cowpea in cowpea-maize relay cropping led to increase of overall yields and improved soil fertility compared to monocropping of maize.
The altitude of any location is associated with climatic conditions and significantly influences crop growth rate and productivity (Katsura et al., 2008). Air density and temperature decrease while the intensity of solar light and ultraviolet rays increase with the gradual increase of altitude. Moreover, it influences the level and duration of precipitation (Jing \& Jichao, 2012). Carbon dioxide, the main driver of photosynthesis is greatly influenced by the altitude as its partial pressure in air reduces with increasing altitude (Sakata \& Yokoi, 2002; Kumar et al., 2005).

Since the Second World War, use of commercial fertilisers has been tremendously increased and led to higher yield of crops to fulfil the food needs of increasing population in developing countries. In particular, utilisation of $\mathrm{N}$ fertilisers contributed to $30-40 \%$ increase in total crop production. Excessive application of $\mathrm{N}$ fertiliser causes nitrate to accumulate in soil and leaches to underground water resulting in human health and environmental issues (Thole, 2007). Spatial arrangement of rows in intercropping is important in determining the growth and production of companion crops. Row pattern is an important plant management practice in intercropping that ensures accessibility of intercropping crops to available resources in soil and favourable microclimate. Seeding crops with normal row geometries recommended for monocropping would not be feasible for better performances under intercropping. Hence, finding an appropriate geometrical modification for intercropping multiple crops in the vicinity would be essential to have better utilisation of available land and input resources (Zhang \& Li, 2003; Szumigalski \& Van Acker, 2006; Dhima et al., 2007; Carrubba et al., 2008; Mucheru-Muna et al., 2010). Modifications in conventional row pattern of intercrops makes it successful and often profitable, as hostile effects on the growth and yield of component crops are reduced to a larger extent through alteration of row patterns (Feng et al., 2019). The present research was executed to assess the relative production efficiency of maize-based intercropping systems established at multiple altitudes in mountain ecosystems under different agronomic management practices.

\section{METHODOLOGY}

\section{Study area}

Research experiments were conducted in the summer season (27 June - 17 October) of years 2015, 2016 and 2017 at farmer's fields in three districts (Gilgit, Hunza 
and Ghizer) of Gilgit-Baltistan region of Pakistan. The experimental locations had varying climatic conditions and elevations from mean sea level: $1500 \mathrm{~m}\left(135.9202^{\circ} \mathrm{N}\right.$ $\left.74.3080^{\circ} \mathrm{E}\right), 1800 \mathrm{~m}\left(36.1025^{\circ} \mathrm{N} 73.4600^{\circ} \mathrm{E}\right)$ and 2200 $\mathrm{m}\left(36.3167^{\circ} \mathrm{N} 74.6500^{\circ} \mathrm{E}\right)$. Mean air temperature was greater during summer season than winter season, whereas, accumulated rainfall was higher in winter season compared to summer season (Figure 1).

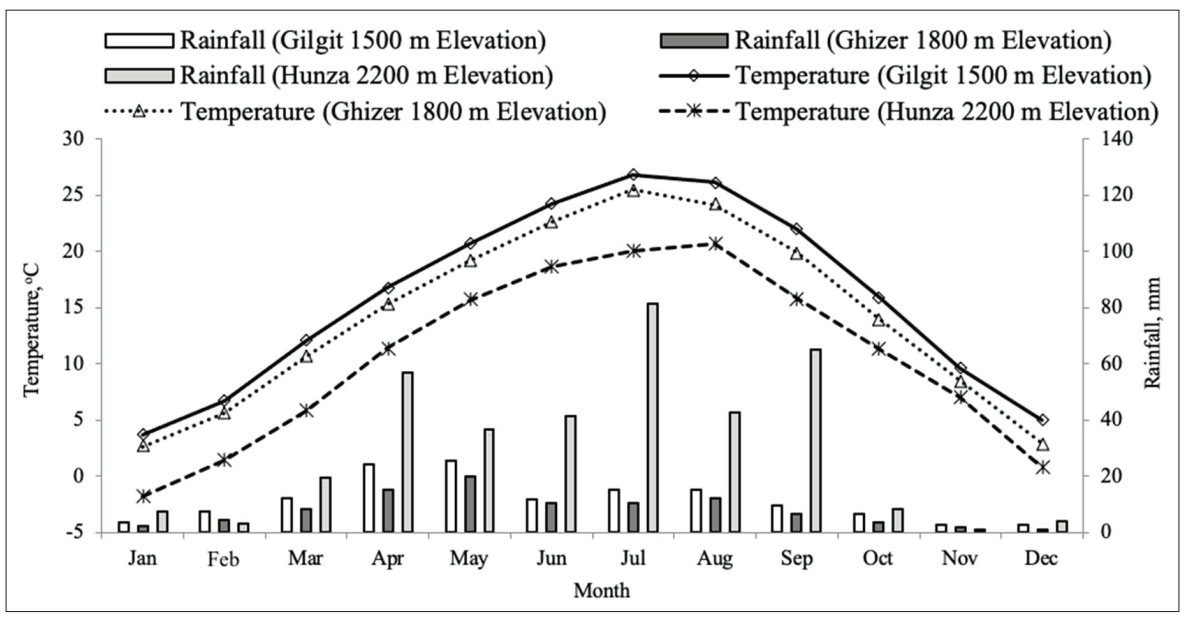

Figure 1: Mean temperature and rainfall of study areas round the year

\section{Treatments and experimental layout}

At each experimental location, treatments were arranged in a factorial combination using RCBD experimental design with three blocks to minimize the effect of slope (uncontrolled variable). During the $1^{\text {st }}$ year (2015), treatments were arranged in combination of $2 \times 3$ including two types of intercropping cropping systems (maize + mungbean and maize + fababean) and three $\mathrm{N}$ levels $\left(28,56,113 \mathrm{~kg} \mathrm{~N} \mathrm{ha}^{-1}\right)$. In the $2^{\text {nd }}$ year (2016), the treatment combination was $2 \times 2$ including two intercropping cropping systems (maize + mungbean and maize + cowpea) and two types of row patterns [alternate single row (ASR) and alternate double row (ADR)]. During the $3^{\text {rd }}$ year $(2017)$, treatment combination was $2 \times 2$ including two intercropping systems (maize + mungbean and maize + soybean) and two types of sowing times (simultaneous and staggered). In simultaneous sowing, both maize and legume were sown at the same time, whereas in staggered treatment plots, maize was sown $15 \mathrm{~d}$ after sowing of legume.

At each experimental site, sole crops of maize and legumes (mungbean, fababean, cowpea and soybean) were also established with 3 replications for comparison. Size of each plot was maintained as $6.0 \mathrm{~m} \times 4.0 \mathrm{~m}$. Treatment plots within each replication were apart by a $1 \mathrm{~m}$ vacant area and replications were separated by a vacant area of $2 \mathrm{~m}$ width. Plant density for maize was maintained as $1 \times 10^{5}$ plants ha ${ }^{-1}$ while for legumes it was $2 \times 10^{5}$ plants $\mathrm{ha}^{-1}$. The said densities were managed by maintaining a $50 \mathrm{~cm}$ space between the rows of maize and legumes, and a plant to plant distance of $20 \mathrm{~cm}$ for maize with $10 \mathrm{~cm}$ for legumes (8 rows per plot for both crops).

\section{Experimental management}

Land was ploughed using a rotary tiller and a disc harrow and was levelled with a plank. Recommended varieties of maize (Azam), mungbean (NM-2006), fababean, cowpea and soybean were sown in sole and intercropping plots as per treatments. Maize plots were irrigated four times during the growing season in 14day intervals after germination. $\mathrm{N}$ dose was applied according to the treatment in splits. Dose of $\mathrm{N}$ was divided into two splits: $50 \%$ was applied as a basal while the remainder $50 \%$ was applied at booting stage in case of simultaneous sowing. For staggered sowing, $\mathrm{N}$ was applied in three splits (25\% at legume sowing, $25 \%$ at maize sowing and $50 \%$ at booting stage of maize). For monocropping of maize, $28 \mathrm{~kg} \mathrm{ha}^{-1}$ as the recommended dose in the area, was used that was supplied in splits (50 $\%$ as basal and $50 \%$ at booting stage). Phosphorus used for intercropping and monocropping plots of maize was applied at the rate of $80 \mathrm{~kg} \mathrm{ha}^{-1}$ and all was used as basal dose. For monocropping of legumes, N, phosphorus and 
potassium were applied at the rate of $30 \mathrm{~kg} \mathrm{ha}^{-1}$ each at the time of sowing. Weeds were controlled manually. Carbofuran granules $(2 \%)$ at the rate of $50 \mathrm{~kg} \mathrm{ha}^{-1}$ was used to control potential insect pests.

\section{Plant sampling and measurements}

Samples of maize and legume plants were taken at maturity. For this, one square meter area $\left(1 \mathrm{~m}^{2}\right)$ was marked in each plot ensuring the representation of the plot. Plants from the marked area were harvested at each experimental site to obtain grain yield. The grains were dried at $70{ }^{\circ} \mathrm{C}$ in an electric oven in the laboratory to a moisture level of $12 \%$ for maize and $9 \%$ for legumes (equation 1). The dried samples were weighed on a digital balance and their weights were recorded for analysis. Thereafter, yield per square meter was calculated and grain production per hectare was computed by multiplying the yield with 10,000 and expressed in $\mathrm{t} \mathrm{ha}^{-1}$ (equation 2).

Moisture content, \% $\frac{\text { (Weight of grains being dried }- \text { Weight of grain dried till constant weight) }}{\text { Weight of grain dried till constant weight }} \times 100$

Yield, $t h a^{-1}=$ Yield, $t m^{-2} \times 10000$

\section{Equivalent yield and relative production efficiency} computation

The equivalent yield (EY) and relative production efficiency (RPE) were computed using yields of component crops in intercropping and monocropping as per equation 3 and equation 4 , respectively.

$$
\begin{aligned}
E Y_{\text {intercropped maize }} & =\text { Intercropped maize yield, } t h a^{-1} \\
& + \text { Intercropped legume yield, } t h a^{-1}
\end{aligned}
$$

$$
R P E=\frac{\left(E Y_{\text {intercropped maize }}-E Y_{\text {sole maize }}\right)}{E Y_{\text {sole maize }}} \times 100
$$

where, EY: equivalent yield $\left(\mathrm{t} \mathrm{ha}^{-1}\right), \mathrm{RPE}$ : relative production efficiency $(\%)$.

\section{Statistical analysis}

For statistical analysis of recorded data the GLM procedure of SAS Program (Version 2.0) was used for data of each year separately as different treatments were followed in different years. Three-way analysis of variance (ANOVA) test was conducted to find the level of significance of factors (altitude, cropping system, $\mathrm{N}$ dose, row pattern, time of sowing) and their interaction on recorded parameters. For means having significant effect, Fisher's protected least significant difference (LSD) test was used to determine the level of difference (De Smith, 2015). Results showing significant difference of means of grain yield of maize and legumes, and for
EY and RPE of cropping systems were presented in the form of graphs.

\section{RESULTS AND DISCUSSION}

\section{Yield performance of maize}

Grain yield of maize significantly varied among the cropping systems of sole and intercropping in years 2015 and 2016. In year 2015, the grain yield of monocropped maize was in par with that of the maize intercropped with mungbean but significantly greater compared to the yield, where maize was intercropped with fababean (Figure 2a). In year 2016, yield of maize did not vary significantly among the cropping systems tested (Figure 2b). However, in year 2017, the grain yield of monocropped maize was significantly greater compared to both intercropping systems (Figure 2c). Notable influence of intercropped legumes on maize grain yield was also indicated in previous studies (Oroka, 2010; Khan et al., 2012; Arshad \& Ranamukhaarachchi, 2012) where the yield of main crop reduced due to intercrop legumes, caused by increased competition between the intercrops for nutrient and water.

The grain yield of maize significantly varied at different altitudes during all three years. The highest grain yield was observed at the lowest altitude of 1500 $\mathrm{m}$ compared to higher elevations of 1800 and $2200 \mathrm{~m}$ (Figure 2d, 2e, 2f). Varied responses of maize grain yield to different elevations were also noted by Ekasingh et al. (2004) and Xue-jun et al. (2013). Different elevations are accompanied with diverse environmental conditions including air temperature, humidity and concentration of $\mathrm{CO}_{2}$ (Jing \& Jichao, 2012). Intercropped maize grown in year 2015 under the $\mathrm{N}$ levels of 28, 56 and 
$113 \mathrm{~kg} \mathrm{ha}^{-1}$ exhibited significantly different grain yields. It was greater with the $\mathrm{N}$ dose of $113 \mathrm{~kg} \mathrm{ha}^{-1}$ compared to lower doses of $\mathrm{N}$ (Figure $2 \mathrm{~g}$ ). The increase of maize grain yield by $\mathrm{N}$ is in agreement with studies of Arif et al. (2012), Saleem et al. (2011) and Khogali et al. (2011) where growth and yield of different crops increased with increasing level of $\mathrm{N}$ fertilisers.

Maize was intercropped with legumes using alternate single row and alternate double row patterns in year 2016 at three different altitudes. Maize intercropped with legumes in alternate single row pattern produced significantly higher grain yield compared to alternate double row pattern (Figure 2h). Row patterns or row arrangements in intercropping has a special significance with respect to efficient utilisation of above- and below-ground resources. Row arrangement of different crops determines the extent of shading and photosynthetically active radiation (PAR) intercepted by the plants. In alternate single row pattern, yield performance remained lower owing to shading effect and underground nutrient and water competition due to greater adjacency of maize plants. Similar results were reported by Arshad and Ranamukhaarachchi (2012) for sweet sorghum-legume intercropping.

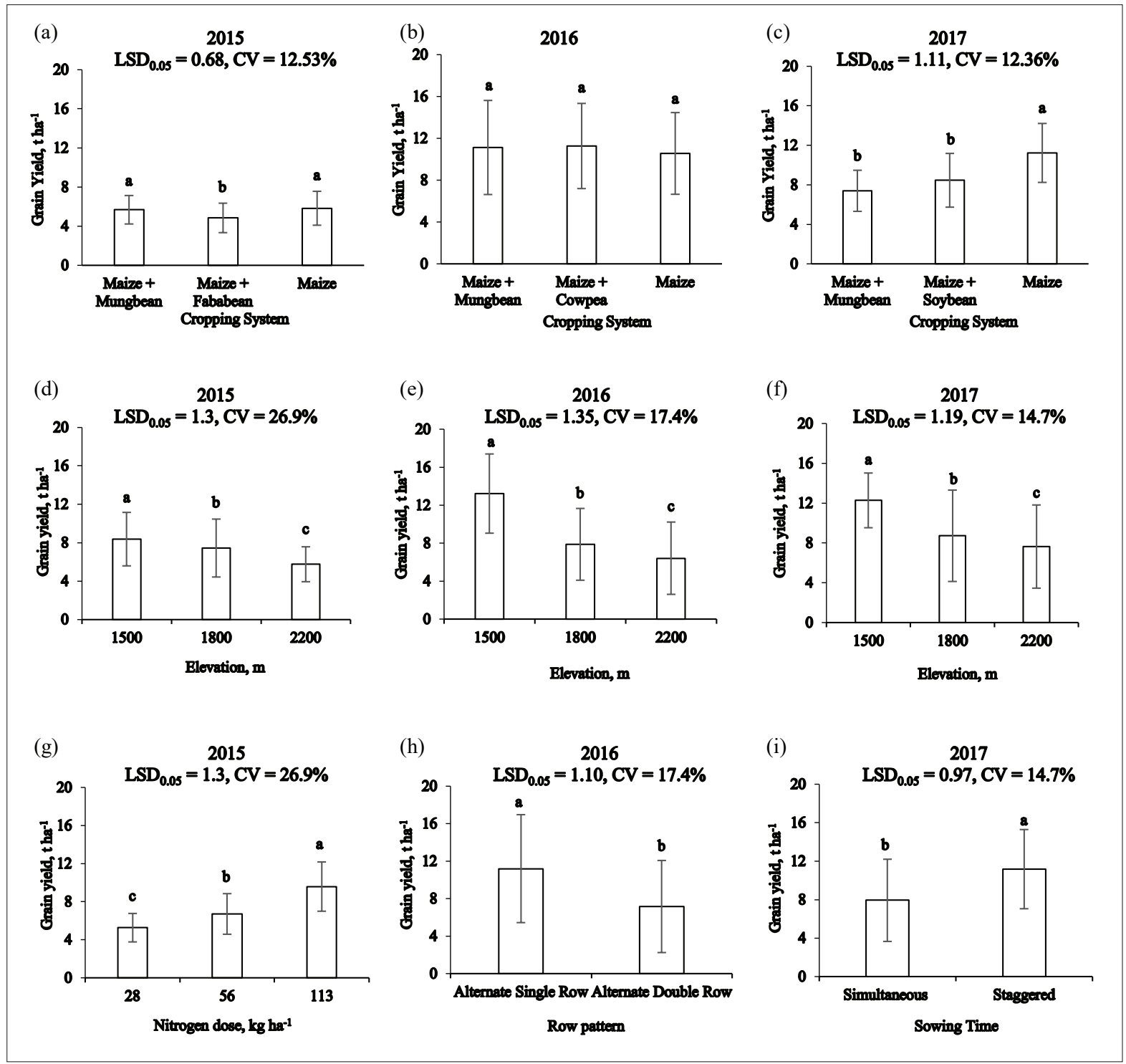

Figure 2: Grain yield of maize influenced by cropping system in year 2015 (a); 2016 (b); 2017 (c); and by altitude in year 2015 (d); 2016 (e); 2017 (f); by dose of nitrogen in year 2015 (g); by row pattern in year 2016 (h) and by time of sowing in year 2017 (i) 


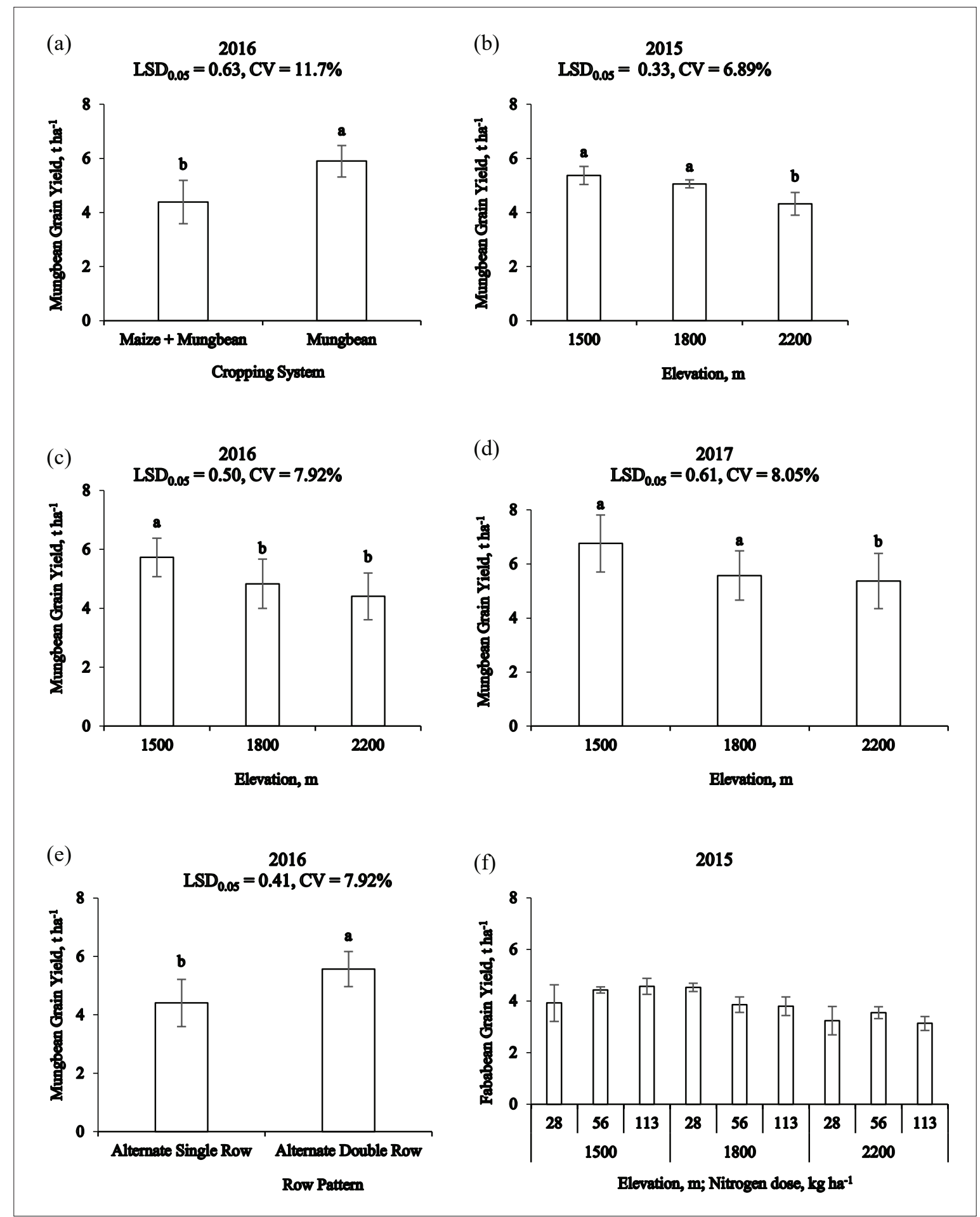

Figure 3: Grain yield of mungbean influenced by cropping system in year 2016 (a); by altitude in year 2015 (b); 2016 (c); 2017 (d); by row pattern in year 2016 (e); grain yield of fababean influenced due to interaction effect of altitude and dose of nitrogen in year 2015 (f). 
During year 2017, maize was intercropped with legumes using two different timings (simultaneous and staggered) at three different altitudes. Maize intercropped with legumes fifteen days after legume seeding (staggered sowing) produced significantly higher grain yield compared to simultaneous intercropping (Figure 2i). Compared to simultaneous intercropping of maize with legumes, staggered intercropping improved the yield performance of both component crops. This overall augmentation of growth and yield in staggered intercropping could be attributed to the complementarity of component crops and the conducive environment provided by different time of sowing (Sharma et al., 2000; Thippeswamy \& Alagundagi, 2001) and availability of adequate quantity of nutrients, especially $\mathrm{N}$, in staggered sowing (Issahaku, 2010).

\section{Mungbean yield}

Mungbean was grown as sole and intercropped with maize for three years at three different altitudes.
Different management practices were used for intercropping systems each year. In year 2016, grain yield of mungbean varied significantly between sole and intercropping stands and was greater in sole cropping compared to intercropping (Figure 3a). The grain yield of mungbean did not vary significantly during the years of 2015 and 2017. Decreased grain yield of intercropped mungbean was also observed by others (Oroka 2010; Arshad \& Ranamukhaarachchi, 2012; Khan et al., 2012). A significant effect of altitude on grain yield of mungbean was observed during all three years. It was significantly greater at $1500 \mathrm{~m}$ compared to $1800 \mathrm{~m}$ and $2200 \mathrm{~m}$ altitudes during the years (Figure 3b, 3c and $3 d)$. Reductions in grain yield of different crops due to intercropping were reported by Smith and Donahue (1991), Terashima et al. (1995) and Sakata and Yokoi (2002).

The yield of mungbean intercropped with maize experienced no differences although the levels of $\mathrm{N}$ applied and time of sowing varied. However, mungbean

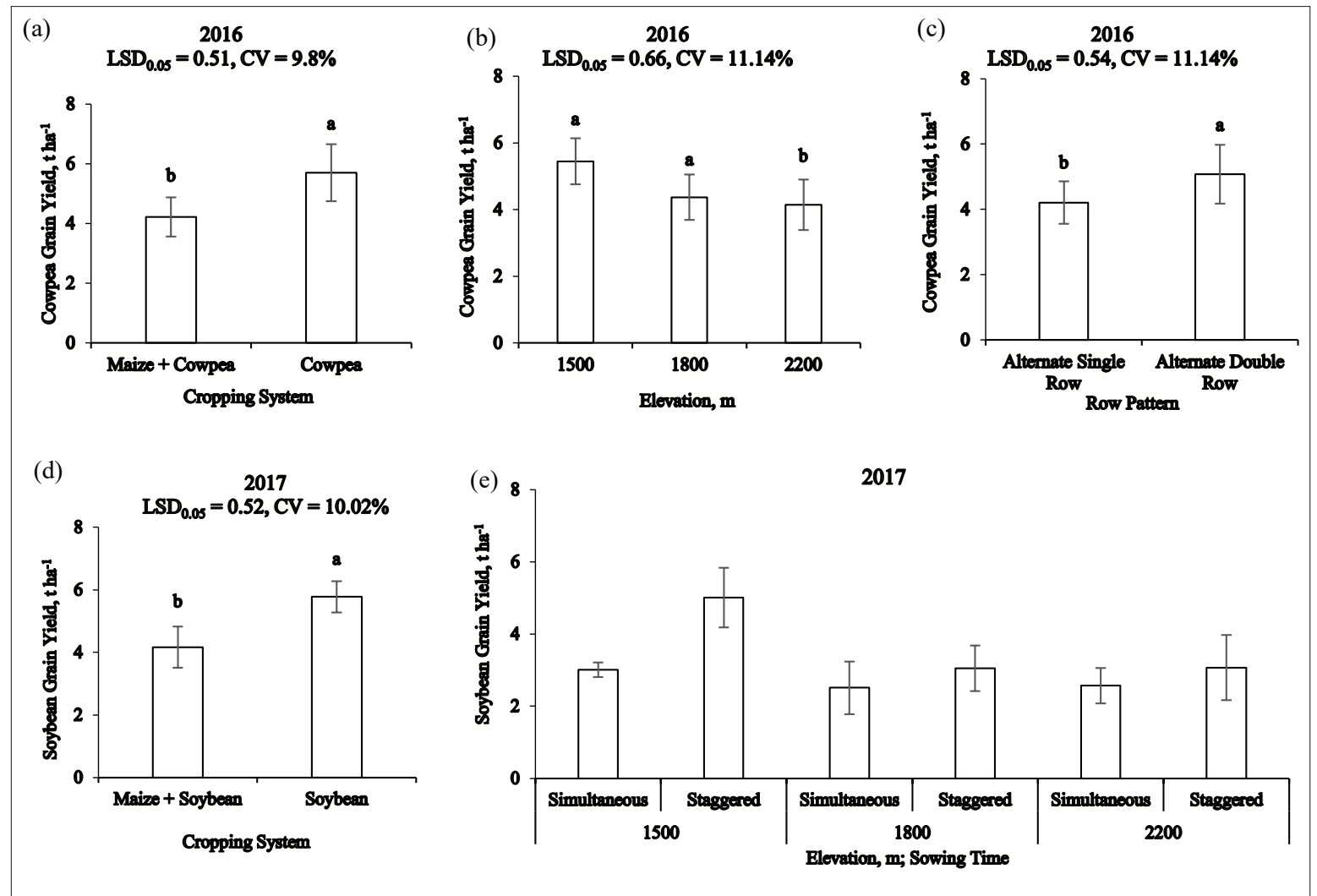

Figure 4: Grain yield of cowpea influenced by cropping system in year 2016 (a); by altitude in year 2016 (b); by row pattern in year 2016 (c); grain yield of soybean influenced by cropping system in year 2017 (d); and due to interaction effect of altitude and time of sowing in year 2017 (e) 
established in alternate double row arrangement yielded significantly greater compared to alternate single row pattern (Figure 3e). The growth and yield of mungbean was optimal in alternate double row arrangement where PAR interception was greater due to wider gap above, and also lower underground resource competition by adequate distance from maize plants. Reduction of legume yield in alternate single row pattern was also reported by Arshad and Ranamukhaarachchi (2012).

\section{Fababean yield}

Grain yield of fababean grown in year 2015 was significantly influenced by the interaction effect of altitude and $\mathrm{N}$ dose. The yield increased with decreasing altitude and increased with increasing dose of N (Figure $3 \mathrm{f}$ ). Yield advantage in crops at lower altitudes was also reported by Terashima et al. (1995) and Sakata and Yokoi (2002). Lower temperature of high altitudes discourages the growth and productivity of crops especially in $\mathrm{C}_{3}$ plants like legumes.

\section{Cowpea yield}

Cowpea was grown as sole and intercrop with maize in year 2016 at three different altitudes. It was significantly influenced by the cropping system, altitude and row pattern. The grain yield was significantly reduced by intercropping compared to its monocropping (Figure 4a). These yield reductions by intercropping are in agreement
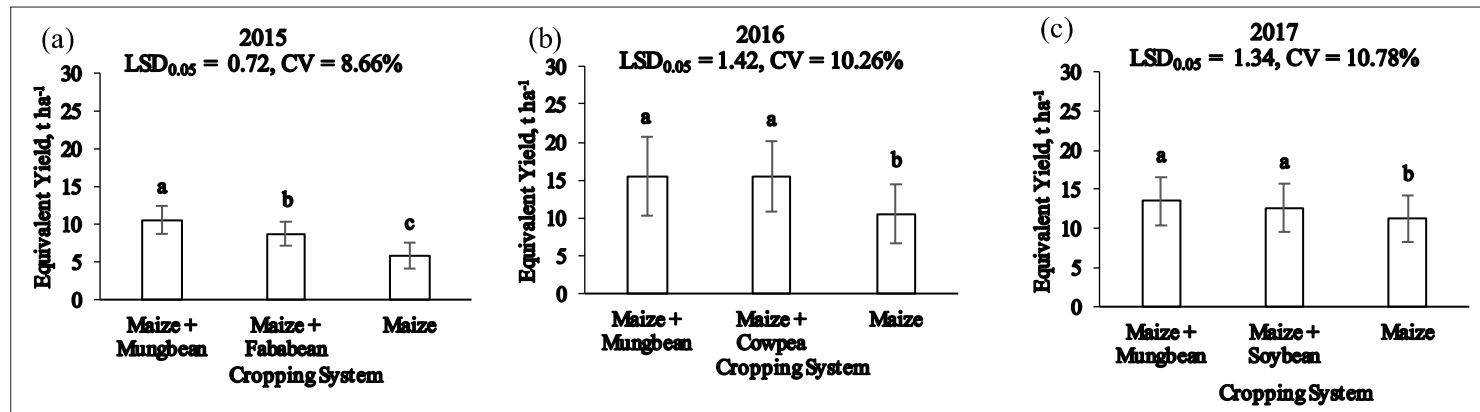

(d)
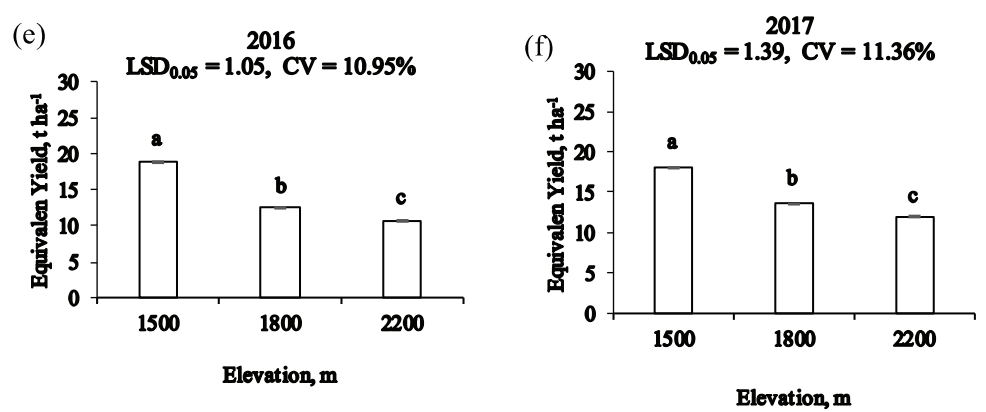

(g)
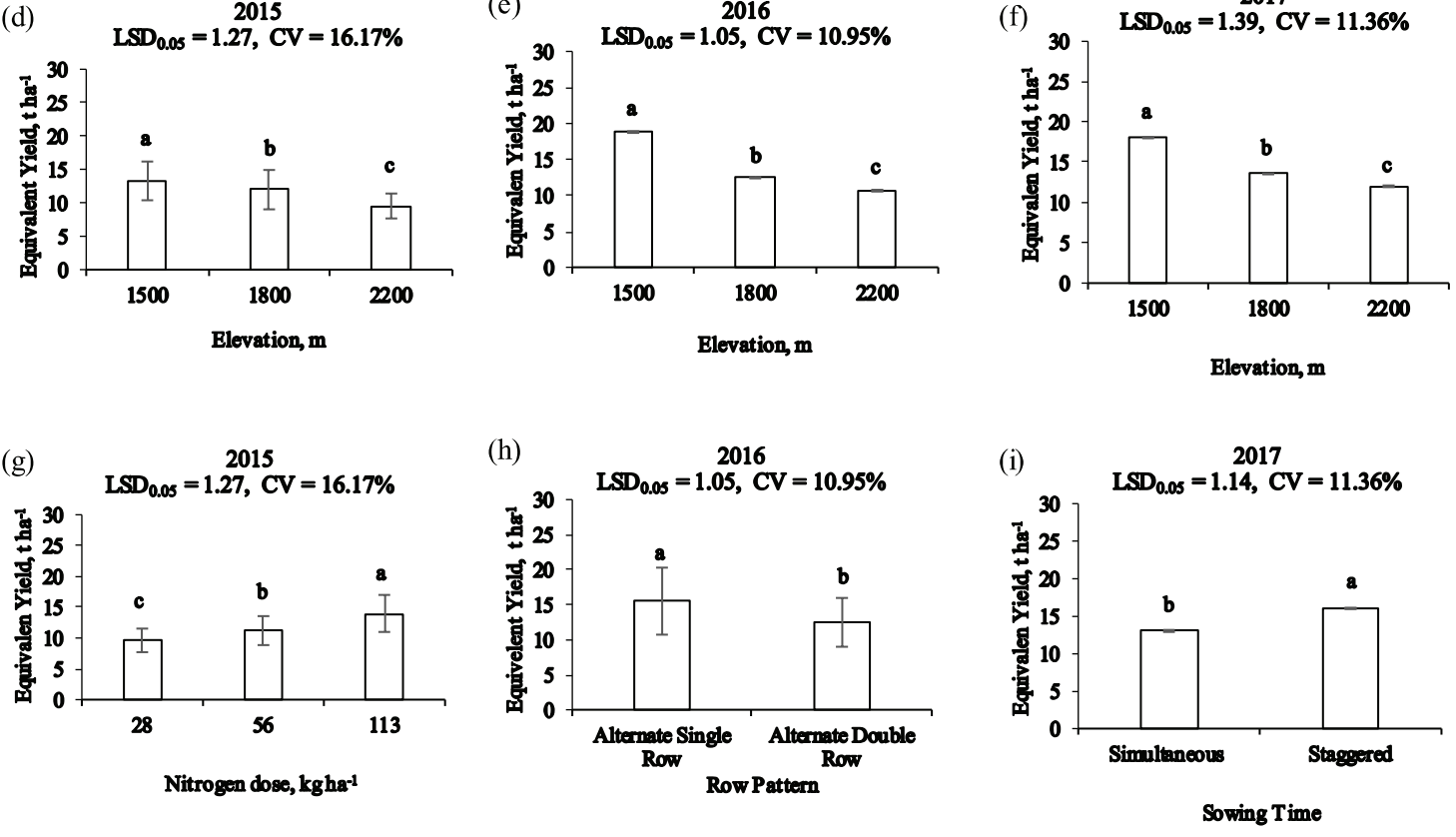

Figure 5: Equivalent yield of maize influenced due to cropping system in year 2015 (a); 2016 (b); 2017 (c); due to altitude in year 2015 (d); 2016 (e); 2017 (f); due to nitrogen dose in year 2015 (g); planting pattern in year 2016 (h); and time of sowing in year 2017 (i) 
with the observations of Onuh et al. (2011). The grain yield was significantly higher at $1500 \mathrm{~m}$ compared to $1800 \mathrm{~m}$ and $2200 \mathrm{~m}$ altitudes (Figure 4b). Cowpea intercropped with maize using alternate double row pattern produced significantly higher yield compared to alternate single row pattern (Figure 4c). Similar performance of different legumes was also noted by Arshad and Ranamukhaarachchi (2012).

\section{Soybean yield}

Soybean was cultivated as sole and intercrop with maize in year 2017 at three different altitudes. Intercropping systems were established with different time of sowing (simultaneous and staggered). Grain yield of soybean significantly varied owing to cropping system and interaction effect of altitude and time of sowing. A significant decrease in grain yield of soybean was noted in intercropping compared to monocropping (Figure $4 d)$. Reduction of yield in sole cropping of different legumes was also reported by Dhar et al. (2013). Grain yield of soybean was significantly reduced as altitude increases, and soybean intercropped fifteen days prior to maize (staggered) gained significantly higher grain yield compared to its simultaneous sowing with maize (Figure 4e). Terashima et al. (1995) reported the altitude effect on yield of plants and Addo-Quaye et al. (2011) observed temporal and spatial variation of yield in intercropping systems.

\section{Maize equivalent yield}

Equivalent yield (EY) is the sum of grain yields of both maize and legumes grown together in intercropping.
Average EY was analysed separately for each year and was compared among the cropping systems, altitudes and management practices. The EY significantly varied among the cropping systems for all three years. It was significantly greater in the case of intercropping systems compared to monocropping of maize for all three years (Figure 5a, 5b and 5c). However, within intercropping systems, significant variation of EY was noted in year 2015 between intercropping of maize with mungbean and maize with fababean (Figure 5a). Greater contribution of the legume partner in addition to better performance of maize in intercropping yielded higher EY for maize + mungbean, maize + cowpea and maize + soybean cropping systems.

The EY was significantly higher at the lowest altitude of $1500 \mathrm{~m}$ compared to $1800 \mathrm{~m}$, and at $1800 \mathrm{~m}$ compared to $2200 \mathrm{~m}$ (Figure 5d, 5e and 5f) during all three years. Favourable growing conditions at lower altitudes encouraged the yield performance of both maize and legumes resulting in higher EY at lower altitudes (He et al. 2013; Horuz et al., 2014). The EY varied significantly at different $\mathrm{N}$ levels and was the highest at $113 \mathrm{~kg} \mathrm{ha}^{-1}$, and significantly reduced at $\mathrm{N}$ dose of 56 and $28 \mathrm{~kg} \mathrm{ha}^{-1}$ in year 2015 (Figure 5g). The $\mathrm{N}$ level of $113 \mathrm{~kg} \mathrm{ha}^{-1}$ boosted the yield performance of maize and finally contributed to greater EY. Alternate single row pattern intercropping of maize and legumes produced greater $\mathrm{EY}$ compared to alternate double row pattern in year 2016 (Figure 5h). Similarly, EY was higher where staggered sowing was followed compared to simultaneous sowing in year 2017 (Figure 4i). Alternate single row pattern and staggered sowing mediated the interspecific competition between maize and legume as also reported by Arshad
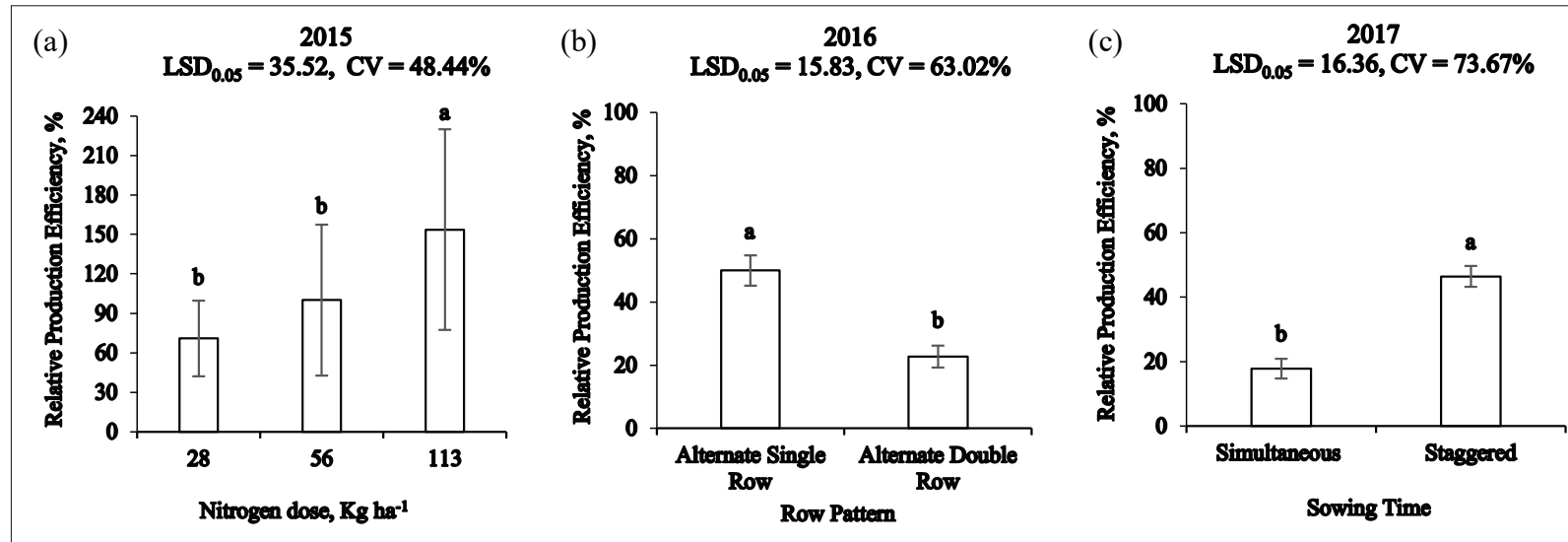

Figure 6: Relative production efficiency of intercropping influenced by nitrogen dose in year 2015 (a); planting pattern in year 2016 (b); and time of sowing in year 2017 (c). 
and Ranamukhaarachchi (2012) for sorghum and legume intercropping.

\section{Intercropping relative production efficiency}

Relative production efficiency (RPE) was computed from equivalent yield after subtracting and dividing by monocropping yield. The RPE shows percentage advantage of intercropping over monocropping. It was computed for each year separately and for the three altitudes. Within intercropping systems, the value of RPE significantly varied by $\mathrm{N}$ dose, row pattern, and time of sowing. The RPE significantly increased with increasing dose of $\mathrm{N}$ and it was the highest at $113 \mathrm{~kg} \mathrm{ha}^{-1}$ (Figure 6a). The grain yield of maize was increased with increasing level of $\mathrm{N}$ dose, which contributed towards greater RPE. Alternate single row pattern gained significantly higher RPE compared to alternate double row arrangement (Figure 6b). Maize rows were more spacious in case of alternate single row pattern resulting in less intraspecific competition and contributing towards greater RPE. Value of RPE increased for intercropping established with staggered sowing compared to simultaneously grown maize and legumes (Figure 6c). Yield variability of cropping systems was also reported by Grover et al. (2009). Similarly, Benites et al. (1993) observed greater RPE values for cereal-legume intercropping systems.

\section{CONCLUSIONS}

This research explored the advantages of intercropping maize with legumes over sole cropping of maize with respect to relative production efficiency. In mountainous areas, lower elevation provides more conducive conditions for greater grain production of both maize and legumes. It was also revealed that in between the rows of maize, rows of legume can be grown as intercrop to increase diversity and relative production efficiency. Moreover, application of $\mathrm{N}$ fertiliser to maize in split doses and its intercropping with legumes in staggered sowing enhanced grain productivity, associated relative yield and relative production efficiency of intercropping. Overall, plant diversity was improved by increasing the number of crops through inclusion of legumes in traditional sole cropping of maize that ascertains sustainability of the cropping system for futuristic food security.

\section{Acknowledgement}

This research was the part of a research grant awarded by the Pakistan Science Foundation (PSF) under the Natural Science Linkage Program (NSLP), where corresponding author of this manuscript (Muhammad Arshad) was the principal investigator. Hence, financial support of PSF is acknowledged.

\section{REFERENCES}

Addo-Quaye A.A., Darkwa A.A. \& Ocloo G.K. (2011). Growth analysis of component crops in a maize-soybean intercropping system as affected by time of planting and spatial arrangement. ARPN Journal of Agricultural and Biological Science 6(6): 34-44.

Amjadian M., Latift N., Farshadfar M. \& Gholipoor M. (2013). Study of intercropping corn and soybean in various planting dates. International. Journal of Agriculture and Crop Science 5(20): 2365-2371.

Arif M., Ali A., Umair M., Munsif F., Ali K., Inamullah, Saleem M. \& Ayub G. (2012). Effect of biochar, FYM and mineral nitrogen alone and in combination on yield and yield components of maize. Sarhad Journal Agriculture 28(2): 191-195.

Arshad M. \& Ranamukhaarachchi S.L. (2012). Effects of legume type, planting pattern and time of establishment on growth and yield of sweet sorghum-legume intercropping. Australian Journal of Crop Science 6(8): 1265-1274.

Ayub M., Tanveer A., Nadeem M.A. \& Shah S.M.A. (2004). Studies on the fodder yield and quality of sorghum grown alone and in mixture with rice bean. Pakistan Journal of Life and Social Sciences 2(1): 46-48.

Benites J.R., McCollum, R.E. \& Naderman G.C. (1993). Production efficiency of intercrops relative to sequentiallyplanted sole crops in a humid tropical environment. Field Crops Research 31(1-2): 1-18.

DOI: https://doi.org/10.1016/0378-4290(93)90046-P

Carrubba A., La Torre R., Saiano F. \& Aiello P. (2008). Sustainable production of fennel and dill by intercropping. Agronomy for Sustainable Development 28: 247-256. DOI: https://doi.org/10.1051/agro:2007040

De Smith M.J. (2015). STATSREF: Statistical Analysis Handbook - a Web-Based Statistics Resource. The Winchelsea Press, Winchelsea, UK.

Dhar P.C., Awal M.A., Sultan M.S. \& Rana M.M. (2013). Interspecific competition, growth and productivity of maize and pea in intercropping mixture. International Journal of Agronomy and Agricultural Research 3(10): 5-12.

Dhima K.V., Lithourgidis A.S., Vasilakoglou I.B. \& Dordas C.A. (2007). Competition indices of common vetch and cereal intercrops in two seeding ratio. Field Crops Research 100: $249-256$.

DOI: https://doi.org/10.1016/j.fcr.2006.07.008

Ekasingh B., Gypmantasiri P., Thong-Ngam K. \& Grudloyma P. (2004). Maize in Thailand: Production Systems, Constraints, and Research priorities. International Maize and Wheat Improvement Center, Mexico.

Feng L., Raza M.A., Chen Y., Khalid M.H.B., Meraj T.A. \& Ahsan F. (2019). Narrow-wide row planting pattern improves the light environment and seed yields of intercrop species in relay intercropping system. PLOS ONE 14(2): $\mathrm{e} 0212885$. 
DOI: https://doi.org/10.1371/journal.pone.0212885

Grover K.K., Karsten H.D. \& Roth G.W. (2009). Corn grain yields and yield stability in four long-term cropping systems. Agronomy Journal 101: 940-946.

DOI: https://doi.org/10.2134/agronj2008.0221x

He Y.H., Yan M., Zhang Q.D., Zhang Z.F., Miao Y.M. \& Bi R.C. (2013). Altitudinal pattern of plant species diversity in the Wulu Mountain Nature Reserve, Shanxi, China. Acta Ecologica Sinica 33: 2452-2462.

DOI: https://doi.org/10.5846/stxb201208181163

Horuz A., Kutbay H.G., Dizman M., Tutar A., Kilic D.D. \& Y1lmaz H. (2014). Nutrient concentrations and nutrient ratios of Rhododendron ponticum litter along an elevational gradient. Ekoloji 23: 1-7.

DOI: https://doi.org/10.5053/ekoloji.2014.911

Issahaku A.R. (2010). Spatial arrangements and time of intercropping an intercrop on the productivity of component crops in maize-soybean intercropping systems. PhD thesis, Kwame Nkrumah University of Science and Technology, PMB Kumasi, Ghana.

Jing L. \& Jichao Y. (2012). Research progress in effects of different altitude on rice yield and quality in China. Greener Journal of Agricultural Sciences 2(7): 340-344.

Khan M.A., Naveed K., Ali K., Ahmad B. \& Jan S. (2012). Impact of mungbean-maize intercropping on growth and yield of mungbean. Pakistan Journal of Weed Science Research 18(2): 191-200.

Khogali M.E., Ahmed E.E.A. \& El Huweris S.O. (2011). Effect of nitrogen, intercropping with lablab bean (Lablab purpureus) and water stress on yield and quality of fodder maize. Journal of Science and Technology 12(3): 55-66.

Katsura K., Maeda S., Lubis I., Horie T., Cao W. \& Shiraiwa T. (2008). The high yield of irrigated rice in Yunnan, China: 'A cross-location analysis'. Field Crops Research 107: $1-11$.

DOI: https://doi.org/10.1016/j.fcr.2007.12.007

Kumar N., Kumar S. \& Ahuja P.S. (2005). Photosynthetic characteristics of Hordeum, Triticum, Rumex, and Trifolium species at contrasting altitudes. Photosynthetica 43: 195201.

DOI: https://doi.org/10.1007/s11099-005-0033-y

Lithourgidis A.S., Dordas C.A., Damalas C.A. \& Vlachostergios D.N. (2011). Annual intercrops: an alternative pathway for sustainable agriculture. Australian Journal of Crop Science 5(4): 396-410.

Marinus W. (2014). Cowpea-maize relay cropping: a method for sustainable agricultural intensification in northern Ghana? MSc. thesis. (minor), PPS 80433 Plant Production Systems. Wageningen University, Netherland.

Mucheru-Muna M., Pypers P., Mugendi D., Kung'u J., Mugwe J., Merckx R. \& Vanlauwe B. (2010). A staggered maize legume intercrop arrangement robustly increases crop yields and economic returns in the highlands of Central Kenya. Field Crops Research 115: 132-139.
DOI: https://doi.org/10.1016/j.fcr.2009.10.013

Onuh M.O., Ohazurike N.C. \& Ijezie A. (2011). Effects of mungbean/melon/maize intercrop on the growth and yield of mungbean (Vigna radiata (L.) Wilczek) cultivated in Owerri rainforest area. World Journal of Agricultural Sciences 7(2): 161-165.

Oroka F.O. (2010). Responses of rice and cowpea intercropping to nitrogen fertiliser and plant population. I. Nodulation, nitrogen fixation and agronomic efficiency. World Journal of Agricultural Sciences 6(2): 154-159.

Sakata T. \& Yokoi Y. (2002). Analysis of the $\mathrm{O}_{2}$ dependency in leaf-level photosynthesis of two Reynoutria japonica populations growing at different altitudes. Plant, Cell and Environment 25: 65-74. DOI: https://doi.org/10.1046/j.0016-8025.2001.00809.x

Saleem R., Ahmed Z.I., Ashraf M., Arif M., Malik M.A., Munir M. \& Khan M.A. (2011). Response of maize-legume intercropping system to different fertility sources under rainfed conditions. Sarhad Journal of Agriculture 27(4): 503-511.

Seran T.H. \& Brintha I. (2010). Review on maize based intercropping. Journal of Agronomy 9(3): 135-145. DOI: https://doi.org/10.3923/ja.2010.135.145

Sharma N.K., Misra O.R., Khushwaha S.S. \& Pachilanya N.K. (2000). Response of sorghum based intercropping system to chemical fertilizers, FYM and crop residues. Research on Crops 1: 289-291.

Smith W.A. \& Donahue R.A. (1991). Simulated influence of altitude on photosynthetic $\mathrm{CO}_{2}$ uptake potential in plants. Plant Cell and Environment 14: 133-136.

DOI: https://doi.org/10.1111/j.1365-3040.1991.tb01380.x

Szumigalski A.R. \& Van Acker R.C. (2006). Nitrogen yield and land use efficiency in annual and sole crops. Agron Journal 98: 1030-1040.

DOI: https://doi.org/10.2134/agronj2005.0277

Terashima N., Atalla R.H., Ralph S.A., Landucci L.L., Lapierre C. \& Monties B. (1995). New preparations of lignin polymer models under conditions that approximate cell wall signification. I. Synthesis of novel lignin polymer models and their structural characterization by ${ }^{13} \mathrm{C}$ NMR. Holzforschung 49: 521-527.

DOI: https://doi.org/10.1515/hfsg.1995.49.6.521

Thippeswamy \& Alagundagi S.C. (2001). Intercropping of legumes with sweet sorghum for higher green forage production. Karnataka Journal of Agricultural Sciences 14: 605-609.

Thole A. (2007). Adaptability of soybeans [Glycine $\max (\mathrm{L})$ Merr] varieties to intercropping under leaf stripped and detasselled Maize (Zea mays L.). M.Sc. thesis, Department of Crop Science, University of Zimbabwe, Zimbabwe.

Wang Z.G., Jin X., Bao X.G., Li X.F., Zhao J.H., Sun J.H. \& Li L. (2014). Intercropping enhances productivity and maintains the most soil fertility properties relative to sole cropping. PLOS ONE 9(12): e113984. 
DOI: https://doi.org/10.1371/journal.pone.0113984

Xue-jun C., Guang-cai C., Qun S., Dong-bin W., Jing C., Yaiong Y., Jie L. \& Wei L. (2013). Altitude effects on maize growth period and quality traits. Acta Ecologica Sinica 33(4): 233-236.

DOI: https://doi.org/10.1016/j.chnaes.2013.05.002

Zhang Y., Liu J., Zhang J., Liu H., Liu S., Zhai L. \& Yin C. (2015). Row ratios of intercropping maize and soybean can affect agronomic efficiency of the system and subsequent wheat. PLOS ONE 10(6): e0129245.
DOI: https://doi.org/10.1371/journal.pone.0129245

Zhang F. \& Li L. (2003). Using competitive and facilitative interactions in intercropping systems enhances crop productivity and nutrient-use efficiency. Plant and Soil 248: $305-312$.

DOI: https://doi.org/10.1023/A:1022352229863

Zougmore R., Kmbou F.N., Quattara K. \& Guillobez S. (2000). Sorghum-cowpea intercropping: an effective technique against run-off and soil erosion in the Sahel. Arid Soil Research and Rehabilitation 14: 329-342.

DOI: https://doi.org/10.1080/08903060050136441 